\title{
PENGARUH KESEHATAN DAN KESELAMATAN KERJA (K3) DAN KEPUASAN KERJA TERHADAP KINERJA KARYAWAN PADA TERMINAL BAHAN BAKAR MINYAK (TBBM) PT. PERTAMINA (PERSERO) PEMATANGSIANTAR
}

\author{
Oleh: \\ Kemas Ardian Putra \\ S1 Manajemen \\ Darwin Lie, Marisi Butarbutar, Stefi Inggrid Thressa
}

Abstraksi

Penelitian ini dilakukan dengan mengunakan teknik analisis deskriptif kualitatif dan deskriptif kuantitatif yang terdiri dari analisis regresi linier berganda, analisis korelasi dan koefisien determinan. Populasi pada pada penelitian ini adalah seluruh karyawan Terminal Bahan Bakar Minyak (TBBM) PT. Pertamina (Persero) Pematangsiantar, berjumlah 53 orang. Pengumpulan data dilakukan dengan kuesioner, wawancara dan dokumentasi. Hasil penelitian dapat disimpulkan sebagai berikut: 1) Karyawan setuju dengan penerapan kesehatan dan keselamatan kerja, kepuasan kerja dan kinerja karyawan sudah tinggi. 2) Hasil analisis regresi adalah $\hat{Y}=4,434+0,312 X_{1}+0,636 X_{2}$ berarti kesehatan dan keselamatan kerja serta kepuasan kerja berpengaruh positif terhadap kinerja. 3) hasil analisis korelasi diperoleh nilai $r=0,771$ artinya terdapat hubungan yang kuat dan positif antara kesehatan dan keselamatan kerja dan kepuasan kerja terhadap kinerja karyawan Terminal Bahan Bakar Minyak (TBBM) PT. Pertamina (Persero) Pematangsiantar. Tinggi rendahnya kinerja karyawan dapat dijelaskan oleh kesehatan dan keselamatan kerja serta kepuasan kerja dapat sebesar 59,5\%. 4) Hipotesis $\mathrm{H}_{0}$ ditolak, artinya kesehatan dan keselamatan kerja dan kepuasan kerja berpengaruh positif dan signifikan terhadap kinerja karyawan Terminal Bahan Bakar Minyak (TBBM) PT. Pertamina (Persero) Pematangsiantar.

Adapun saran dari hasil penelitian ini adalah perusahaan agar melengkapi alat perlindungan diri karyawan, pemberian tanda peringatan dan bahaya pada area kerja, kelengkapan alat pelindung kerja, ketersedian klinik di area kerja. Perusahaan lebih memperhatikan dan lebih dekat kepada karyawan dan memberikan kesempatan kepada karyawan berinovasi dalam bekerja dan menimbulkan kreativitas karyawan sehingga kinerja karyawan lebih meningkat.

Kata kunci: Kesehatan dan Keselamatan Kerja, Kepuasan Kerja dan Kinerja

\section{Abstraction}

This research was conducted by using descriptive analysis techniques of qualitative and quantitative descriptive consisting of multiple linear regression analysis, correlation analysis and determinant coefficient. The population in this study were all employees of Terminal Bahan Bakar Minyak (TBBM) PT. Pertamina (Persero) Pematangsiantar, totaling 53 people. Data was collected by questionnaire, interview and documentation. Results of the study can be summarized as follows: 1) Employees agree with the implementation of health and safety at work, job satisfaction and employee performance is already high. 2) The results of the regression analysis is $Y=4.434+0,312 X 1+0,636 X 2$ means health and safety as well as job satisfaction has positive influence on performance. 3 ) the results of the analysis of correlation was obtained $r=0.771$ means that there is a strong and positive relationship between health and safety and job satisfaction to employees performance Terminal Bahan Bakar Minyak (TBBM) PT. Pertamina (Persero) Pematangsiantar. The level of employee performance can be explained by occupational health and safety and job satisfaction can be 59.5\%.4) The hypothesis $\mathrm{HO}$ is rejected, meaning that health and safety and job satisfaction and significant positive effect on employee performance Terminal Bahan Bakar Minyak (TBBM) PT. Pertamina (Persero) Pematangsiantar.

The suggestion of this research is the company that employees complete personal protective equipment, provision of warning signs and dangers in the work area, completeness labor protective equipment, availability of clinics in the work area. Companies pay more attention and closer to employees and provide the opportunity for employees to innovate in their work and raises employee creativity so that employee performance is increased.

Keywords: Health and Safety at Work, Job Satisfaction and Performance

\section{A. PENDAhuluan}

1. Latar Belakang Masalah

Terminal Bahan Bakar Minyak (TBBM) PT.

Pertamina (Persero) Pematangsiantar merupakan perusahaan yang bergerak di bidang Industri Bahan
Bakar Minyak. Dari hasil wawancara dengan asisten administrasi umum dan sekuriti TBBM PT. Pertamina (Persero) Pematangsiantar dari 53 orang karyawan, kinerja karyawan yang baik $28 \%$ dan 72 $\%$ cukup baik. 
Pelaksanaan kesehatan dan keselamatan kerja Terminal Bahan Bakar Minyak (TBBM) PT. Pertamina (Persero) Pematangsiantar mengacu pada Undang-undang No. 1 Tahun 1970 dan Undangundang No. 13 tahun 2003 paragrap 5 pasal 86 dan 87. Dalam meningkatkan kinerja karyawan TBBM PT. Pertamina (Persero) Pematangsiantar melaksanakan program kesehatan dan keselamatan kerja, yang terdiri dari aspek kesehatan, keselamatan, keamanan, lingkungan dan Training Health Sefety Environment (HSE).

Terminal Bahan Bakar Minyak (TBBM) PT. Pertamina (Persero) Pematangsiantar menilai kepuasan kerja yang tinggi dari beberapa aspek, diantaranya pekerjaan itu sendiri adalah setiap kegiatan operasional perusahaan mulai dari penerimaan, penimbunan dan penyaluran bahan bakar minyak.

Untuk meningkatkan kinerja karyawan yang efektif dan efisien untuk itu, TBBM PT. Pertamina (Persero) Pematangsiantar harus menerapkan kesehatan dan keselamatan kerja sesuai dengan peraturan perundang-undangan yang berlaku dan memberikan kepuasan kerja kepada karyawan agar kinerja karyawan tercapai.

\section{Rumusan Masalah}

a. Bagaimana gambaran kesehatan dan keselamatan kerja (K3), kepuasan kerja dan kinerja karyawan pada TBBM PT. Pertamina (Persero) Pematangsiantar?

b. Bagaimana pengaruh kesehatan dan keselamatan kerja (K3) dan kepuasan kerja terhadap kinerja karyawan pada TBBM PT. Pertamina (Persero) Pematangsiantar secara simultan dan parsial?

\section{Tujuan Penelitian}

a. Untuk mengetahui gambaran kesehatan dan keselamatan kerja (K3), kepuasan kerja dan kinerja karyawan pada TBBM PT. Pertamina (Persero) Pematangsiantar.

b. Untuk mengetahui pengaruh kesehatan dan keselamatan kerja (K3) dan kepuasan kerja terhadap kinerja karyawan pada TBBM PT. Pertamina (Persero) Pematangsiantar secara simultan dan parsial.

\section{Metode Penelitian}

Penelitian ini mengambil lokasi di Terminal Bahan Bakar Minyak (TBBM) Pematangsiantar merupakan unit pemasaran regional I PT. PERTAMINA (PERSERO) yang beralamat di Jl. Bola Kaki No. 1 Kelurahan Banjar, Kecamatan Siantar Barat, Kota Pematangsiantar. Pada penelitian ini yang menjadi populasi adalah seluruh karyawan yang terdapat pada TBBM PT. Pertamina (Persero) Pematangsiantar yang berjumlah 53 orang ( $\mathrm{N}=53)$.

Adapun Desain penelitian yang digunakan dalam penulisan penelitian ini adalah Penelitian Kepustakaan (Library Research) dan Penelitian Lapangan (Field Research). Teknik pengumpulan data yang dilakukan penulis dalam penelitian ini adalah berupa Kuesioner, Wawancara dan
Dokumentasi. Adapun jenis data yang digunakan dalam penelitian ini adalah jenis data kualitatif dan data kuantitatif. Hasil data yang diperoleh dari lapangan akan dianalisis secara deskriptif baik bersifat kualitatif dan kuantitatif.

\section{B. LANDASAN TEORI}

\section{Manajemen Sumber Daya Manusia}

Menurut Mondy (2008:10), manajemen sumber daya manusia adalah pemanfaatan sejumlah individu untuk mencapai tujuan-tujuan organisasi. Menurut Mathis dan John (2011:3), manajemen sumberdaya manusia adalah rancangan sistem-sistem formal dalam sebuah organisasi untuk memastikan penggunaan bakat manusia secara efektif dan efisien guna mencapai tujuan-tujuan organisasi. Dari pendapat para ahli diatas, penulis menyimpulkan bahwa manajemen sumber daya manusia adalah cara atau sistem yang digunakan untuk memanfaatkan dan mendayagunakan bakat manusia untuk mencapai tujuan dan sasaran perusahaan secara efektif dan efisien.

Menurut Mondy (2008:4), fungsi manajemen sumberdaya manusia adalah penyediaan staf, pengembangan SDM, kompensasi, keselamatan dan kesehatan.

\section{Kesehatan dan Keselamatan Kerja (K3)}

Menurut Mondy dan Noe (2005:360), keselamatan kerja adalah sebuah kondisi dimana para karyawan terlindung dari cedera yang disebabkan oleh berbagai kecelakaan yang berhubungan dengan perkerjaan dan kesehatan kerja adalah sebuah kondisi dimana karyawan terbebas dari berbagai penyakit fisik dan emosional yang disebabkan oleh perkerjaan. Sedangkan menurut Mathis dan John (2006:50), bahwa keselamatan adalah merujuk pada perlindungan terhadap kesejahteraan fisik seseorang terhadap cedera yang terkait dengan perkerjaan. Kesehatan adalah kondisi umum fisik, mental, dan emosional seseorang yang sehat untuk melakukan pekerjaan. Dari teori diatas dapat disimpulkan bahwa kesehatan dan keselamatan kerja mempunyai arti penting dalam suatu perusahaan yang akan berdampak pada produktivitas karyawan.

Menurut Pertamina (2015), aspek-aspek keselamatan dan keamanan dalam bekerja dan beraktivitas, terdiri dari kesehatan, keselamatan, keamanan, aspek lingkungan dan Training Health Safety Environment (HSE).

\section{Kepuasan Kerja}

Menurut Luthans (2005:243), kepuasan kerja adalah hasil dari persepsi pegawai mengenai seberapa baik pekerjaan mereka memberikan hal yang dinilai penting. Menurut Mangkunegara (2006:117), kepuasan kerja adalah suatu perasaan yang menyokong atau tidak menyokong diri pegawai yang berhubungan dengan pekerjaannya maupun dengan kondisi dirinya. Berdasarkan uraian pendapat ahli diatas, penulis menyimpulkan bahwa kepuasan kerja suatu keadaan yang dirasakan para karyawan 
terhadap keadaan atau kondisi pekerjaannya dan lingkungan kerja yang sesuai dengan keinginan karyawan dan peraturan yang berlaku pada perusahaan tersebut.

\section{Kinerja Karyawan}

Menurut Mathis dan John (2006:378), kinerja (performance) pada dasarnya adalah apa yang dilakukan atau tidak dilakukan oleh karyawan. Kinerja karyawan yang umum untuk kebanyakan pekerjaan meliputi elemen seperti: kuantitas dan kualitas dari hasil, kehadiran dan kemampuan bekerja sama. Menurut Dessler (2006:87), kinerja adalah prestasi aktual karyawan atau pegawai dibandingkan dengan prestasi yang diharapkan dari karyawan atau pegawai. Dari beberapa pendapat ahli di atas, dapat disimpulkan bahwa kinerja merupakan suatu kondisi yang harus diketahui dan dikonfirmasikan kepada pihak tertentu mengetahui tingkat pencapaian hasil suatu instansi dihubungkan dengan visi yang diemban suatu organisasi atau perusahaan serta mengetahui dampak positif dan negatif dari suatu kebijakan opersional.

Menurut Mathis dan John (2006:378), dimensi yang berhubungan dengan kinerja adalah kuantitas, kualitas, ketepatan waktu, kehadiran dan kemampuan bekerja sama.

\section{Pengaruh Kesehatan dan Keselamatan Kerja (K3) dan Kepuasan Kerja \\ Terhadap Kinerja}

Menurut Sutrisno (2012:74), kepuasan kerja adalah suatu sikap karyawan terhadap pekerjaan yang berhubungan dengan situasi kerja, kerja sama antar karyawan, imbalan yang diterima dalam kerja dan hal-hal yang menyangkut faktor fisik dan psikologis. Menurut Panggabean (2004:134), kepuasan kerja berhubungan dengan semangat kerja. Jika seseorang merasa puas terhadap perlakuan yang diterima di tempat kerja mereka akan bersemangat untuk kerja melebihi apa yang diharapkan.

Dari uraian teori ahli diatas dapat disimpulkan bahwa kesehatan dan keselamatan kerja secara efektif dan efisien yang dilaksanakan oleh perusahaan akan meningkatkan produktivitas dan kepuasan kerja akan memberikan semangat dalam bekerja dan akan meningkatkan kinerja karyawan untuk mencapai tujuan dari perusahaan.

\section{PEMBAHASAN}

\section{Analisa}

\section{a. Deskriptif Kualitatif}

Adapun penetapan kriteria nilai rata-rata jawaban dari responden tersebut dimasukan kedalam kelas-kelas interval dimana penentuan intervalnya memakai rumus sebagai berikut:

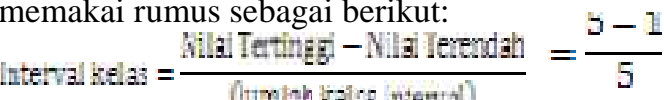

$$
\begin{aligned}
& =0,8
\end{aligned}
$$

Dari rumus diatas dapat diperoleh interval kelas 0,8 sehingga berlaku ketentuan kategori dengan hasil sebagai berikut:
Tabel 1

Nilai Interval dan Kategori Jawaban Responden

\begin{tabular}{|c|c|c|c|}
\hline \multirow{2}{*}{$\begin{array}{l}\text { Nital } \\
\text { Internal }\end{array}$} & \multicolumn{3}{|c|}{ Kelangeri } \\
\hline & 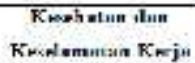 & kepmasm kerja & $\begin{array}{l}\text { Kincj: } \\
\text { Kungewen }\end{array}$ \\
\hline$n-1, m$ & Faryal Thlak Fxik & 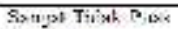 & Sxilypi Thisk Fatik \\
\hline $181-2 \sin$ & Tid $x \in$ F Foik & Titak Thes & Tia-k Fis \\
\hline $2,01 \quad 9,20$ & Celan: Lails & Conup Puas & Como bials \\
\hline $5,71,1,20$ & Dalk & Puas: & $y=2 x$ \\
\hline $1,2 t \quad 2,30$ & Sarsant liak & Siazit tevis: & Sagget Hel \\
\hline
\end{tabular}

Sumber: hasil pengolahan data

1) Gambaran Pelaksanaan Kesehatan dan Keselamatan Kerja pada Terminal Bahan Bakar Minyak (TBBM) PT. Pertamina (Persero) Pematangsiantar

Dari tabel jawaban responden, dapat diketahui dimensi kesehatan (health) yaitu untuk indikator usaha perusahaan untuk mencegah penyakit yang disebabkan oleh pekerjaan berada di rata-rata 4.41 yang dinilai sangat baik, hal ini disebabkan oleh perusahaan memperhatikan kesehatan para karyawannya. Indikator perusahaan dalam menciptakan iklim kerja yang sehat dinilai 4.09 dikategorikan baik. Hal ini disebabkan karena perusahaan menjamin lingkungan kerja agar tetap sehat.

Dari dimensi keselamatan (safety), untuk indikator perhatian perusahaan terhadap keselamatan kerja bernilai rata-rata 4.60 berkriteria sangat baik. Hal ini disebabkan oleh perusahaan telah menyediakan alat perlindungan diri untuk para karyawan berkerja di zona berbahaya sesuai dengan standar operasi perusahaan dan sesuai dengan keadaan lingkungan zat berbahaya. Untuk indikator menghindari kecelakaan dalam bekerja dengan nilai rata-rata 4.41 berkriteria sangat baik. Hal ini dikarenakan perusahaan menyediakan alat perlindungan diri yang lengkap dan selalu memberikan safety talk seminggu sekali untuk mengingatkan dan memberikan penyuluhan tentang bahaya dan dampak kecelakaan kerja.

Dimensi keamanan (security) dalam indikator usaha dalam menjaga aset perusahaan bernilai ratarata 4.09 yang dikategorikan baik. Hal ini disebabkan setiap area TBBM PT. Pertamina (Persero) Pematangsiantar dilengkapi CCTV agar bisa mengontrol kegiatan yang ada dalam TBBM PT. Pertamina (Persero) Pematangsiantar. Untuk indikator usaha perusahaan dalam mengelola operasi yang tidak terhenti apabila ada ganguan keamanan yang bernilai 4.11 yang berkriteria baik. Hal ini disebabkan karena TBBM PT. Pertamina (Persero) dikelilingi oleh pagar berduri dan pihak perusahaan selalu berkordinasi dengan pihak kepolisian untuk selalu bersinergi dalam mengatasi masalah gangguan keamanan.

Selanjutnya untuk dimensi aspek lingkungan (environment) dengan indikator bagaimana perusahaan mengelola limbah yang berbahaya berada pada nilai rata-rata 3.30 yang bernilai cukup baik. Hal ini disebabkan minyak yang ditimbulkan mudah terbakar pihak TBBM PT. Pertamina (Persero) Pematangsiantar menyediakan bak khusus 
penampungan limbah berbahaya untuk diolah menjadi limbah yang ramah lingkungan dan tidak berbahaya. Untuk indikator apabila terjadi tumpahan minyak, bagaimana usaha perusahaan dalam mengelolah tumpahan minyak tersebut bernilai ratarata 4.60 yang berkriteria sangat baik. Hal ini dikarenakan setiap tangki timbun disediakan waduk untuk menampung tumpahan minyak apabila terjadi kebocoran atau luapan saat pengisian kedalam tangki timbun.

Dimensi training HSE untuk indikator kemampuan HSE setiap pimpinan bernilai 4.30 yang bernilai sangat baik. Hal ini disebabkan karena setiap karyawan rutin diberikan bimbingan dan penyuluhan tentang kesehatan dan keselamatan kerja yang meningkatkan kemampuan dan pemahaman tentang kesehatan dan keselamatan kerja. Untuk indikator pelatihan HSE yang diberikan perusahaan bernilai 4.18 berkriteria baik. Hal ini disebabkan oleh perusahaan rutin memberikan pelatihan dan pengembangan.

Secara keseluruhan, hasil dari kuesioner kesehatan dan keselamatan kerja memperoleh nilai rata-rata 4.20 yang berkriteria baik, pada indikator nilai rata-rata tertinggi adalah 4.60 dari perhatian perusahaan terhadap keselamatan kerja dan apabila terjadi tumpahan minyak, usaha perusahaan mengelolah tumpahan minyak tersebut. Untuk nilai terendah ada pada indikator perusahaan mengelolah limbah yang berbahaya dengan nilai 3.30 yang bernilai cukup baik.

\section{2) Gambaran Kepuasan Kerja Pada Terminal Bahan Bakar Minyak (TBBM) PT. Pertamina (Persero) Pematangsiantar}

Dari tabel jawaban responden dapat dilihat dimensi pekerjaan itu sendiri dengan indikator posisi kerja saat ini di perusahaan bernilai rata-rata 3,77 yang berkriteria puas. Hal ini disebabkan oleh perusahaan mampu menempatkan karyawan pada posisi dan kemampuan yang mereka miliki. Untuk indikator kesempatan untuk mengembangkan keterampilan karyawan dalam pekerjaan sekarang bernilai rata-rata 4,07 yang berkriteria puas. Hal ini disebabkan, setiap karyawan memiliki kemampuan dan keterampilan masing-masing karyawan.

Dari dimensi gaji dengan indikator gaji yang diterima karyawan memiliki nilai rata-rata 4,60 yang berkriteria sangat puas, hal ini disebabkan perusahaan menetapkan gaji karyawan diatas UMR dan untuk indikator pemberian tunjangan oleh perusahaan memiliki nilai rata-rata 3.49 yang berkriteria puas, hal ini dikarenakan tunjangan yang diberikan kepada karyawan sesuai dengan kinerja karyawan, misalnya lembur, THR, dan tunjangan pensiun.

Untuk dimensi kesempatan untuk promosi dengan indikator kesempatan promosi berdasarkan kinerja karyawan bernilai rata-rata 3,32 yang berkriteria cukup puas, hal ini disebabkan karena perusahaan memberikan kesempatan promosi kepada karyawan yang berprestasi berdasarkan kinerja karyawan dan indikator kesempatan promosi berdasarkan lama kerja bernilai rata-rata 4,07 yang berkriteria puas, hal ini dikarenakan karyawan yang memiliki masa kerja yang lebih lama dan memiliki pengalaman yang lama pada perusahaan.

Selanjutnya untuk dimensi mutu pengawasan supervisi dengan indikator puas jika selalu diawasi saat bekerja bernilai rata-rata 3,15 yang berkriteria cukup puas, hal ini disebabkan karena karyawan merasa dipandang dan dihargai dalam bekerja dan untuk indikator bekerja sesuai dengan apa yang telah ditetapkan bernilai rata-rata 3,49 yang berkriteria puas, hal ini disebabkan karyawan merasa lebih diperhatikan dalam berkerja.

Selanjutnya untuk dimensi rekan kerja dengan indikator interaksi antar sesama rekan kerja bernilai rata-rata 3,98 yang berkriteria puas, hal ini disebabkan oleh karyawan peduli sesama rekan kerja dan untuk indikator perhatian sesama rekan kerja bernilai rata-rata 3,88 yang berkriteria puas, hal ini disebabkan hubungan kekeluargaan antar sesama rekan kerja terjalin dengan baik dan harmonis.

Secara keseluruhan kepuasan kerja karyawan dengan dimensi pekerjaan itu sendiri, gaji, kesempatan promosi, mutu pengawasan supervisi dan rekan kerja memiliki nilai rata-rata 3,78 yang berkriteria puas. Nilai rata-rata kepuasan kerja tertinggi ada pada indikator gaji yang diterima 4,60 yang berkriteria sangat puas. Dan nilai rata-rata kepuasan terendah berada pada indikator 3,15 yang berkriteria cukup puas.

3) Gambaran Kinerja Karyawan Pada Terminal Bahan Bakar Minyak (TBBM) PT. Pertamina Pematangsiantar

Kinerja karyawan yang dilaksanakan Terminal Bahan Bakar Minyak (TBBM) PT. Pertamina (Persero) Pematangsiantar diukur oleh dimensi kuantitas dari hasil kinerja karyawan. Hal yang berkaitan dengan kuantitas kinerja karyawan adalah hasil yang dicapai karyawan semaksimal mungkin, untuk mengetahui tinggi rendahnya hasil kinerja karyawan tersebut dibandingkan dengan target yang telah ditetapkan oleh perusahaan. Dimensi kualitas dari kinerja karyawan sebagai penyempurna dari hasil kinerja karyawan. Kualitas yang dihasilkan seberapa baik dan tepat waktu karyawan dalam menyelesaikan pekerjaan.

Selanjutnya dimensi ketepatan waktu para karyawan Terminal Bahan Bakar Minyak (TBBM) PT. Pertamina (Persero) Pematangsiantar dilaksanakan untuk melihat sejauh mana kinerja karyawan dan sesuai tidaknya dengan waktu yang telah dijadwalkan, untuk dimensi kehadiran para karyawan tercermin dari ketepatan waktu hadir dan pulang dari tempat kerja sesuai dengan waktu yang telah ditetapkan oleh perusahaan. Indikator kemapuan bekerja sama kepada rekan-rekan kerja karyawan, hal ini memungkinkan karyawan bekerja lebih efektif dan menyelesaikan pekerjaan dengan se-efektif mungkin.

Dari tabel jawaban responden dapat dilihat bahwa dimensi kuantitas dari indikator hasil kerja yang diperoleh karyawan berada pada nilai rata-rata 
4.11 kriteria baik. Hal ini disebabkan Terminal Bahan Bakar Minyak (TBBM) PT. Pertamina (Persero) Pematangsiantar memberikan jaminan kesehatan dan keselamatan kerja yang dapat meningkatkan dan mencapai target kerja yang telah ditetapkan oleh perusahaan. Untuk indikator tingkat pencapaian target kerja karyawan berada pada nilai rata-rata 4.09 yang berkriteria baik. Hal ini dikarenakan kinerja karyawan selalu meningkat yang membuat pencapaian target kerja karyawan meningkat.

Dimensi kualitas dari indikator kualitas hasil kerja yang dihasilkan oleh karyawan bernilai ratarata 4.11 yang berkriteria baik. Hal ini disebabkan oleh setiap karyawan selalu menjalakan pekerjaannya berkomitmen menghasilkan mutu yang terbaik sesuai standar perusahaan. Indikator ketelitian karyawan dalam menyelesaikan pekerjaan bernilai rata-rata 4.13 yang berkriteria baik, hal ini disebabkan setiap karyawan dalam melaksanakan pekerjaan selalu berhati-hati dan teliti dalam setiap pekerjaannya.

Selanjutnya untuk dimensi ketepatan waktu dengan indikator bagaimana efisiensi waktu dalam menyelesaikan pekerjaan bernilai rata-rata 4.30 berkriteria sangat baik, karena tingkat ketepatan waktu karyawan dalam melaksanakan pekerjaan sangat baik dan efisien dengan memanfaatkan waktu semaksimal mungkin agar waktu tidak terbuang siasia. Untuk indikator pencapaian karyawan menyelesaikan pekerjaan dengan tenggang waktu bernilai rata-rata 4.60 berkriteria sangat baik, karena karyawan selalu menyelesaikan suatu pekerjaan dengan tepat waktu dan merasa tertantang untuk secepat mungkin untuk menyelesaikan pekerjaan.

Dari dimensi kehadiran dengan indikator tingkat kehadiran karyawan bernilai rata-rata 3.88 yang berkriteria baik, hal ini disebabkan oleh karyawan selalu hadir dalam bekerja dan jarang absen dengan alasan tertentu. Untuk indikator kehadiran karyawan dalam kegiatan senam pagi, apel pagi dan kegiatan lainnya di perusahaan bernilai rata-rata 4.60 yang berkriteria sangat baik, hal ini disebabkan oleh karyawan selalu hadir dalam setiap kegiatan yang memberikan motivasi dan semangat kepada karyawan dalam berkerja.

Selanjutnya untuk dimensi kemampuan karyawan bekerja sama dengan indikator kemampuan karyawan untuk bekerja sama dengan tim dan pimpinan memiliki nilai rata-rata 3.86 yang berkriteria baik, hal ini disebabkan oleh karyawan selalu memahami untuk mencapai hasil yang seefektif dan se-efisiensi mungkin karyawan harus bekerjasama untuk mencapai hasil tersebut. Dan indikator kemampuan karyawan bekerjasama dengan rekan kerja bernilai rata-rata 3.30 yang berkriteria cukup baik, hal ini dikarenakan karyawan mampu bekerjasama dengan baik.

Secara keseluruhan nilai kinerja karyawan memiliki nilai rata-rata 4.10 yang berkriteria baik. Nilai jawaban responden tertinggi ada pada indikator pencapaian karyawan menyelesaikan pekerjaan dengan tenggang waktu bernilai 4.60 berkriteria sangat baik dan nilai jawaban responden terendah berada pada indikator kemampuan karyawan bekerjasama dengan rekan kerja bernilai rata-rata 3.30 yang berkriteria cukup baik.

\section{b. Deskriptif Kuantitatif}

\section{1) Analisa Regresi Linear Berganda}

Analisis regresi linier berganda digunakan untuk mengetahui pengaruh variabel bebas $(\mathrm{X})$ dan variabel terikat $(\mathrm{Y})$, dimana $\mathrm{X} 1$ adalah kesehatan dan keselamatan kerja, X2 kepuasan kerja dan Y adalah kinerja karyawan. Maka dilakukan perhitungan menggunakan program aplikasi SPSS untuk memperoleh nilai a dan $\mathrm{b}$ dengan notasi sebagai berikut: $\hat{Y}=a+b_{1} X_{1}+b_{2} X_{2}$

Tabel 2

Regresi Linier Berganda Coefficients ${ }^{a}$

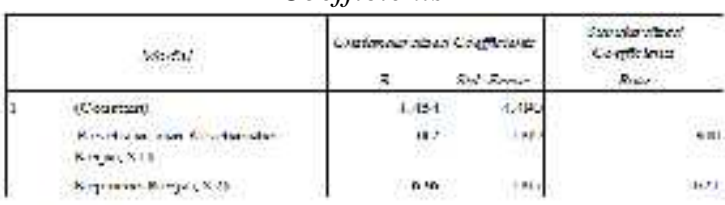

a. Dependent Variable: Kinerja Karyawan

Sumber: hasil perhitungan SPSS Statistics 17.00

Dari hasil analisis regresi dengan SPSS pada tabel 17 diatas diperoleh koefisien regresi $b_{1}$ sebesar 0,312 dan $b_{2}$ sebesar 0,636 sehingga dapat diketahui persamaan regresi yang diperoleh adalah : $\hat{\mathrm{Y}}=4,434+0,312 \mathrm{X}_{1}+0,636 \mathrm{X}_{2}$, artinya terdapat pengaruh yang positif antara variabel kesehatan dan keselamatan kerja (X1) dan variabel kepuasan kerja (X2) terhadap kinerja (Y) pada Terminal Bahan Bakar Minyak (TBBM) PT. Pertamina (Persero) Pematangsiantar.

\section{2) Analisis Korelasi dan Koefisien Determinasi}

Untuk menghitung kekuatan hubungan kesehatan dan keselamatan kerja dan kepuasan kerja terhadap kinerja karyawan dilakukan analisis korelasi, berupa derajat atau kedalaman hubungan fungsional yang menjelaskan hubungan antara perubah, dinyatakan dengan koefisien korelasi yang disimbolkan dengan $r$. Nilai $r$ dapat dilihat melalui tabel berikut ini:

Tabel 3

Koefisien Korelasi dan Koefisien Determinasi Model Summary ${ }^{b}$

\begin{tabular}{|c|c|c|c|c|}
\hline ¿ASAS & $x$ & As sower & 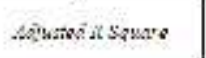 & 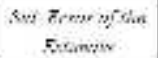 \\
\hline & .7915 & 305 & $2 / \mathrm{s}$ & $2 m:$ \\
\hline
\end{tabular}

a. Predictors: (Constant), Variabel X (Kesehatan dan Keselamatan Kerja)

b. Dependent Variable: Variabel Y (Kinerja Karyawan)

Sumber: hasil perhitungan SPSS Statistics 17.0

Dari tabel di atas, didapat $\mathrm{r}=0,771$ yang artinya terdapat hubungan yang kuat dan positif antara kesehatan dan keselamatan kerja dan kepuasan kerja terhadap kinerja karyawan Terminal Bahan Bakar Minyak (TBBM) PT. Pertamina (Persero) Pematangsiantar. Selanjutnya diperoleh koefisien determinasi $\mathrm{R}$ square 0,595 artinya tinggi 
rendahnya kesehatan dan keselamatan kerja dan kepuasan kerja dapat dijelaskan sebesar 59,5\% oleh kinerja karyawan, selebihnya 40,5\% dijelaskan oleh faktor-faktor lain seperti kepemimpinan, prestasi kerja, motivasi, kompensasi, pengembangan karir dan faktor-faktor lain yang tidak dibahas dalam penelitian ini.

\section{3) Uji Simultan (Uji F)}

Uji $F$ digunakan untuk mengetahui apakah varibel bebas berpengaruh terhadap kinerja karyawan secara bersama-sama atau simultan. Pengujian ini dilakukan untuk membandingkan antara $\mathrm{F}_{\text {hitung }}$ dan $\mathrm{F}_{\text {tabel }}$ pada taraf signifikansi sebesar $5 \%$ atau $\alpha=0,05$ dengan menggunakan program aplikasi SPSS, dapat dilihat dari tabel berikut: Tabel 4

Perkiraan Nilai F hitung

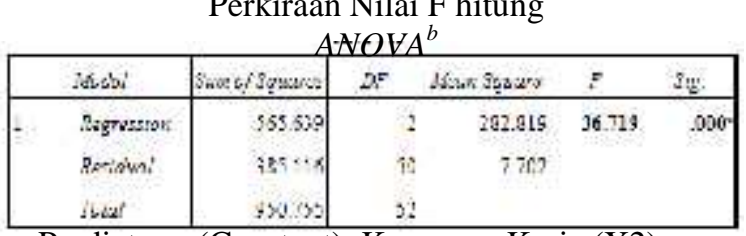

a. Predictors: (Constant), Kepuasan Kerja (X2),

Kesehatan dan Keselamatan Kerja (X1)

b. Dependent Variable: Kinerja Karyawan (Y)

Sumber: hasil perhitungan SPSS Statistics 17.0

Berdasarkan tabel di atas diperoleh nilai $F_{\text {hit }}$ sebesar 36,719 sedangkan $F_{\text {tabel }}(0,05 ; 50$ VS 2) sebesar 3,18 atau dengan taraf signifikan $0,000<\alpha$ 0,05, maka $\mathrm{H}_{0}$ ditolak, artinya kesehatan dan keselamatan kerja dan kepuasan kerja berpengaruh positif dan signifikan terhadap kinerja karyawan pada Terminal Bahan Bakar Minyak (TBBM) PT. Pertamina (Persero) Pematangsiantar secara simultan.

\section{4) Uji Parsial (Uji t)}

Untuk menghasilkan suatu kesimpulan yang valid, maka harus dilakukan uji hipotesis (uji t). Dari hasil perhitungan koefisien korelasi diketahui bahwa kesehatan dan keselamatan kerja, kepuasan kerja dan kinerja karyawan sangat berhubungan, untuk menguji kebenarannya maka dilakukan pengujian hipotesis dengan mengunakan program aplikasi SPSS, dapat dilihat dari tabel berikut ini:

Tabel 5

Perkiraan Nilai thitung

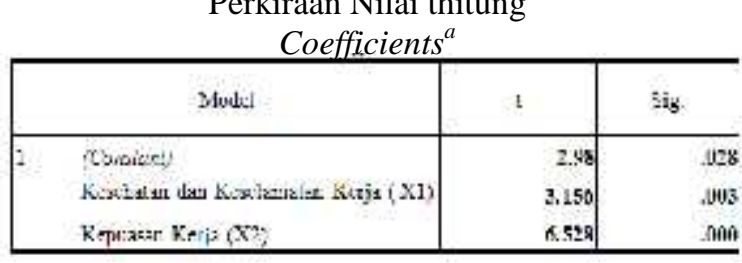

a. Dependent Variable: Variabel Y

Sumber: Hasil perhitungan SPSS Statistics 17.0

Dari tabel di atas dapat dilihat nilai $t_{\text {hit }}$ pada variabel $X_{1}$ sebesar 3,156 sedangkan $t_{\text {tabel }}$ dengan $\mathrm{df}$ $=\mathrm{n}-\mathrm{k}-1 \quad(53-2-1=50)$ sebesar 2,0085, atau dengan taraf signifikan $0,003<\alpha 0,05$, maka $\mathrm{H}_{0}$ ditolak dan $\mathrm{H}_{\mathrm{a}}$ diterima, artinya kesehatan dan keselamatan kerja berpengaruh positif dan signifikan terhadap kinerja karyawan pada Terminal Bahan Bakar Minyak
(TBBM) PT. Pertamina (Persero) Pematangsiantar secara parsial. Kemudian nilai $t_{\text {hit }}$ pada variabel $\mathrm{X}_{2}$ sebesar 6,528 sedangkan $\mathrm{t}_{\text {tabel }}$ dengan $\mathrm{df}=\mathrm{n}-\mathrm{k}-1$, (53$2-1=50$ ) sebesar 2,0085, atau dengan taraf signifikan $0,000<\alpha 0,05$, maka $\mathrm{H}_{0}$ ditolak dan $\mathrm{H}_{\mathrm{a}}$ diterima, artinya kepuasan kerja berpengaruh positif dan signifikan terhadap kinerja karyawan pada Terminal Bahan Bakar Minyak (TBBM) PT. Pertamina (Persero) Pematangsiantar secara parsial.

\section{Evaluasi}

a. Kesehatan dan Keselamatan Kerja Pada Terminal Bahan Bakar Minyak (TBBM) PT.

\section{Pertamina (Persero) Pematangsiantar}

Berdasarkan dimensi yang digunakan dalam penelitian ini, hasil yang diperoleh dapat dijelaskan bahwa kesehatan dan keselamatan kerja yang ada pada Terminal Bahan Bakar Minyak (TBBM) PT. Pertamina (Persero) Pematangsiantar dapat dikatakan baik, hal tersebut dibuktikan berdasarkan hasil kuesioner yang diperoleh nilai rata-rata 4.20 berkriteria baik.

Namun ada beberapa indikator dinilai baik tetapi masih dibawah nilai rata-rata, yaitu pada indikator perhatian perusahaan dalam menciptakan iklim yang sehat dengan nilai rata-rata 4,09 berkriteria baik. Cara untuk mengatasi indikator tersebut perusahaan menyediakan klinik di area perusahaan, menata ruangan yang nyaman untuk bekerja, mengatur sirkulasi udara di dalam ruangan.

Selanjutnya pada dimensi security (keamanan) pada indikator usaha perusahaan dalam menjaga aset perusahaan dengan nilai rata-rata 4,09 yang berkriteria baik. Cara yang dilakukan perusahaan agar tidak kehilangan aset perusahaan adalah dengan memasang kamera CCTV di area yang strategis, agar setiap kegiatan yang ada dalam perusahaan bisa terkontrol. Untuk indikator usaha perusahaan dalam mengelolah operasi yang tidak terhenti apabila ada gangguan keamanan bernilai rata-rata 4,11 yang berkriteria baik. Dalam hal ini, perusahaan harus terus berkoordinasi dengan pihak aparat dalam menjaga situasi apabila ada gangguan keamanan, dan pihak perusahaan harus memasang pagar berduri untuk menjaga agar kerusuhan tidak masuk kedalam lingkungan perusahaan sehingga kegiatan operasional perusahaan tidak terganggu.

Dimensi aspek lingkungan untuk indikator perusahaan dalam mengelolah limbah yang berbahaya yang bernilai 3,30 yang berkriteria cukup baik. dalam hal ini perusahaan harus membangun lab. khusus penampungan limbah dan mengelolah limbah tersebut menjadi limbah yang ramah lingkungan. Dimensi training HSE dari indikator pelatihan $H S E$ yang diberikan perusahaan bernilai rata-rata 4,18 yang berkriteria baik. Perusahaan harus memberikan pelatihan dan pengembangan yang berkaitan dengan kesehatan dan kecelakaan kerja setiap 4 bulan sekali.

b. Kepuasan Kerja Pada Terminal Bahan Bakar
Minyak (TBBM) PT. Pertamina (Persero) Pematangsiantar 
Terminal Bahan Bakar Minyak (TBBM) PT. Pertamina (Persero) Pematangsiantar berupaya memberikan kepuasan kepada para karyawannya agar kinerja karyawan bisa lebih baik lagi. Dimensi kepuasan kerja karyawan yang terdiri dari pekerjaan itu sendiri, gaji, kesempatan promosi, mutu pengawasan supervisi, dan rekan kerja bernilai ratarata 3,78 yang berkriteria puas.

Namun, ada beberapa indikator yang perlu ditingkatkan seperti indikator posisi kerja saat ini di perusahaan dengan nilai rata-rata 3,77 yang berkriteria puas. Hal ini perlu dilakukan rotasi atau mutasi jabatan sesuai dengan kemampuan dan keahlian karyawan, agar karyawan merasa lebih segar. Untuk indikator pemberian tunjangan yang diterapkan perusahaan yang bernilai rata-rata 3,49 berkriteria puas. Tunjangan yang diberikan perusahaan harus ditingkatkan, apabila kinerja karyawan lebih meningkat tunjangan yang didapat oleh karyawan harus meningkat, untuk mendorong semangat karyawan dalam bekerja.

Untuk indikator kesempatan promosi berdasarkan kinerja yang bernilai rata-rata 3,32 berkriteria cukup puas. Perusahaan memberikan tunjangan yang lebih tinggi untuk jabatan yang lebih tinggi, agar memicu kinerja karyawan bertambah lebih baik lagi. Dimensi mutu pengawasan supervisi dengan indikator selalu diawasi saat bekerja dengan nilai rata-rata 3,15 dengan kriteria cukup puas. Hal ini pengawasan yang dilakukan oleh perusahaan telah benar, namun perusahaan juga harus memberikan kesempatan para karyawan untuk berkreasi dan berinovasi dalam bekerja. Untuk indikator bekerja sesuai dengan apa yang telah ditetapkan bernilai rata-rata 3,49 yang berkriteria puas. Untuk itu, perusahaan diharapkan tidak memasang target terlalu tinggi yang membuat karyawan merasa tertekan. Perusahan memberi target yang diperkirakan bisa dicapai, dan pada saat peningkatan target karyawan telah siap dengan target tersebut.

\section{c. Kinerja Karyawan Pada Terminal Bahan Bakar Minyak (TBBM) PT. Pertamina (Persero) Pematangsiantar}

Terminal Bahan Bakar Minyak (TBBM) PT. Pertamina (Persero) Pematangsiantar mencapai tujuan perusahaan melalui kinerja para karyawan. Kinerja karyawan pada Terminal Bahan Bakar Minyak (TBBM) PT. Pertamina (Persero) Pematangsiantar dapat dinilai baik, hal ini bisa dibuktikan dengan nilai rata-rata 4.10 dalam penelitian ini.

Dalam penilaian kinerja karyawan darì dimensi kuantitas dengan indikator tingkat pencapaian target kerja karyawan pada rata-rata 4,09 yang dinilai baik, namun untuk meningkatkan target kerja karyawan perusahaan harus memberi kompensasi untuk memicu semangat karyawan dalam bekerja. Selanjutnya untuk dimensi kehadiran dengan indikator tingkat kehadiran karyawan selama bekerja bernilai rata-rata 3,88 yang berkriteria baik. Namun, kehadiran karyawan harus lebih ditingkatkan dengan cara tetap memberikan waktu libur di hari minggu dan hari besar dan memberi sangsi yang tegas terhadap karyawan yang sering absen dalam bekerja.

Selanjutnya untuk dimensi kemampuan bekerja sama dengan indikator kemampuan karyawan bekerja sama dengan tim dan pimpinan berada pada nilai rata-rata 3,86 yang berkriteria baik, hal ini harus ditingkatkan agar bisa menunjang hasil yang lebih maksimal dengan cara memberikan motivasi dan edukasi terhadap karyawan agar bisa saling bekerja sama. Pada indikator kemampuan karyawan dalam bekerja sama dengan rekan kerja bernilai rata-rata 3,30 yang bernilai cukup baik. Hal ini juga harus diperhatikan, agar karyawan bisa saling memahami dan mengerti dalam bekerja sama.

\section{KESIMPULAN DAN SARAN}

\section{Kesimpulan}

a. Hasil analisis deskriptif kualitatif kesehatan dan keselamatan kerja pada Terminal Bahan Bakar Minyak (TBBM) PT. Pertamina (Persero) Pematangsiantar berada pada nilai 4,20 yang berkriteria baik. Indikator nilai tertinggi ada pada indikator tanpa insiden dan tumpahan minyak yang bernilai rata-rata 4,60. Selanjutnya, masih terdapat kelemahan pada indikator tanpa limbah berbahaya pada nilai rata-rata 3,30 yang berkriteria cukup baik.

b. Hasil analisis deskriptif kualitatif kepuasan kerja pada Terminal Bahan Bakar Minyak (TBBM) PT. Pertamina (Persero) Pematangsiantar berada pada nilai rata-rata 3,78 yang berkriteria puas. Jawaban respon nilai rata-rata tertinggi ada pada indikator puas terhadap gaji dengan nilai rata-rata 4,60 yang berkriteria sangat puas. Selanjutnya terdapat kelemahan pada indikator perhatian supervisi pada nilai rata-rata 3,15 yang berkriteria cukup puas.

c. Hasil analisis deskriptif kualitatif kinerja karyawan pada Terminal Bahan Bakar Minyak (TBBM) PT. Pertamina (Persero) Pematangsiantar berada pada nilai 4,10 yang berkriteria baik. Nilai rata-rata tertinggi berada pada indikator penyelesaian dengan tenggang waktu bernilai 4,60 yang berkriteria sangat baik. Selanjutnya untuk kelemahan pada indikator tanggung jawab yang dibebankan bernilai ratarata 3,30 yang berkriteria cukup baik.

d. Hasil analisis regresi yang diperoleh persamaan $\hat{\mathrm{Y}}=4,434+0,312 \mathrm{X}_{1}+0,636 \mathrm{X}_{2}$, artinya terdapat pengaruh positif antara variabel kesehatan dan keselamatan kerja (X1) dan variabel kepuasan kerja (X2) terhadap kinerja karyawan (Y) pada Terminal Bahan Bakar Minyak (TBBM) PT. Pertamina (Persero) Pematangsiantar. Dimana semakin baik pelaksanaan kesehatan dan keselamatan kerja yang diberikan perusahaan dan karyawan merasa puas dalam pekerjaannya maka semakin tinggi kinerja yang diberikan karyawan untuk perusahaan.

e. Hasil analisis korelasi diperoleh nilai $r=0,771$ menunjukan bahwa terdapat hubungan yang kuat 
dan positif antara kesehatan dan keselamatan kerja dan kepuasan kerja terhadap kinerja karyawan Terminal Bahan Bakar Minyak (TBBM) PT. Pertamina (Persero) Pematangsiantar. Nilai koefisien determinasi yaitu 0,595 , artinya tinggi rendahnya kesehatan dan keselamatan kerja dan kepuasan kerja dapat dijelaskan sebesar 59,5\% oleh kinerja karyawan, selebihnya $40,5 \%$ dijelaskan oleh faktor-faktor lain seperti kepemimpinan, prestasi kerja, motivasi, kompensasi, pengembangan karir dan faktor-faktor lain yang tidak dibahas dalam penelitian ini.

f. Hasil hipotesis dengan uji simultan diperoleh nilai $F_{\text {hit }}$ sebesar 36,719 sedangkan $F_{\text {tabel }}(0,05$; 50 VS 2) sebesar 3,18 atau dengan taraf signifikan $0,000<\alpha 0,05$, maka $\mathrm{H}_{0}$ ditolak, artinya kesehatan dan keselamatan kerja dan kepuasan kerja berpengaruh positif dan signifikan terhadap kinerja karyawan pada Terminal Bahan Bakar Minyak (TBBM) PT. Pertamina (Persero) Pematangsiantar secara simultan.

g. Hasil hipotesis dengan uji parsial diperoleh nilai $t_{\text {hitung }} 3,156$ sedangkan $t_{\text {tabel }}$ dengan distribusi frekuensi $=\mathrm{n}-\mathrm{k}-1 \quad(53-2-1=50)$ sebesar 2,0085, atau dengan taraf signifikan $0,003<\alpha 0,05$, maka $\mathrm{H}_{0}$ ditolak dan $\mathrm{H}_{\mathrm{a}}$ diterima, artinya kesehatan dan keselamatan kerja berpengaruh positif dan signifikan terhadap kinerja karyawan pada Terminal Bahan Bakar Minyak (TBBM) PT. Pertamina (Persero) Pematangsiantar. Dan nilai $t_{\text {hit }}$ pada variabel $X_{2}$ sebesar 6,528 sedangkan $t_{\text {tabel }}$ dengan distribusi frekuensi $=\mathrm{n}-\mathrm{k}-1,(53-2-1=50)$ sebesar 2,0085, atau dengan taraf signifikan $0,000<\alpha 0,05$, maka $\mathrm{H}_{0}$ ditolak dan $\mathrm{H}_{\mathrm{a}}$ diterima, artinya kepuasan kerja berpengaruh positif dan signifikan terhadap kinerja karyawan pada Terminal Bahan Bakar Minyak (TBBM) PT. Pertamina (Persero) Pematangsiantar secara parsial.

\section{Saran}

a. Kesehatan dan keselamatan kerja merupakan faktor yang terpenting didalam sebuah perusahaan untuk dapat mencegah terjadinya kecelakaan dan penyakit yang membahayakan karyawan akibat bekerja. Kesehatan dan keselamatan kerja dapat ditingkatkan melalui penyuluhan dan edukasi kepada para karyawan agar setiap karyawan memiliki kesadaran untuk keselamatan dalam bekerja. Perusahaan harus menyediakan dan memfasilitasi seluruh alat perlindungan diri yang lengkap kepada karyawan, terdiri dari pemberian tanda peringatan dan bahaya pada area kerja, kelengkapan alat pelindung kerja, ketersedian klinik di area kerja. Selain itu, perusahaan juga harus member tunjangan kecelakan kerja dan mempermudah segala urusan karyawan yang bersangkutan. b. Dalam memberikan kepuasan kepada para karyawan Terminal Bahan Bakar Minyak (TBBM) PT. Pertamina Pematangsiantar lebih memperhatikan dan lebih dekat kepada karyawan, agar perusahaan tahu dan memahami apa kebutuhan dari karyawan. Dan memberikan kesempatan untuk para karyawan berinovasi dalam bekerja dan menimbulkan kreativitas karyawan agar kinerja karyawan lebih baik lagi.

c. Dalam meningkatkan kinerja karyawan Terminal Bahan Bakar Minyak (TBBM) PT. Pertamina (Persero) Pematangsiantar, perusahaan memberikan pelatihan dan kegiatan-kegiatan olah raga ataupun kegiatan yang bersifat kebersamaan kepada para karyawan dalam bekerjasama baik secara tim maupun kepada rekan kerja.

d. Sehubung dengan keterbatasan yang ada pada penulis, penelitian ini masih terdapat kelemahan dan belum dapat mengungkapkan seluruh variabel yang dapat mempengaruhi kinerja karyawan pada Terminal Bahan Bakar Minyak (TBBM) PT. Pertamina (Persero) Pematangsiantar. Sebagai bahan masukan untuk penelitian selanjutnya, perlu memperbanyak variabel penelitian, seperti: kepemimpinan, prestasi kerja, motivasi, kompensasi, pengembangan karir dan faktor-faktor lain yang tidak dibahas dalam penelitian ini.

\section{E. DAFTAR PUSTAKA}

Dessler, Gary. 2007. Manajeman Sumber Daya Manusia. Edisi kesepuluh. Jilid 2. Jakarta: Indeks.

Luthans, Fred. 2005. Perilaku Organisasi. Edisi Kesepuluh. Yogyakarta: ANDI.

Mathis, Robert L, \& Jackson, John H. 2006. Human Resources Managemant. Edisi Kesepuluh. Jakarta: Salemba Empat.

........, 2011. Manajeman Sumber Daya Manusia. Edisi Kesepuluh. Jakarta: Salemba Empat.

Mangkunegara, A. Anwar Prabu. 2006. Manajeman Sumber Daya Manusia Perusahaan. Bandung: Salemba Empat.

Mondy, Wayne R. 2008. Manajeman Sumber Daya Manusia. Edisi kesepuluh. Jilid 2, Jakarta: Erlangga.

Mondy, Wayne R. \& Noe, Robert, M. 2005. Human Resources Managemant. NinthEditin. USA: Prentice Hall.

Panggabean, Mutiara S. 2004. Manajeman Sumber Daya Manusia. Cetakan Kedua. Bogor: Ghalia Indonesia.

Pertamina. http://www.pertamina.com. Diakses Tahun 2015

Sutrisno, H. Edy. 2012. Manajemen Sumber Daya Manusia. Edisi Pertama. Cetakan Ketiga. Jakarta: Kencana. 